\title{
THE OLD AND THE NEW IN CORN CULTURE
}

H. HOWARD BIGGAR

Office of Corn Investigations, Bureau of Plant Indrestry

\section{CONTENTS}

Corn the Great American Cereal . . . . . . . . . . . 3

Corn and the Early Colonies . . . . . . . . . . . . . . 3

Corn and the Indian . . . . . . . . . . . . . . . 4

Kinds of Corn Grown by the Indians . . . . . . . . . . . 5

Primitive Seed-Testing Methods . . . . . . . . . . . . 6

Primitive Corn-Planting Methods . . . . . . . . . . . . 7

Plants as Indicators of the Season . . . . . . . . . . . 9

Seed Selection and Storing . . . . . . . . . . . . . . . . . .

Indian Corn Foods . . . . . . . . . . . . . . . 10

Primitive and Modern Methods of Culture . . . . . . . . 11

Corn and the Westward Movement . . . . . . . . . . 12

Corn and the Packing Industry . . . . . . . . . . . . 13

The Silo and the Corn Crop . . . . . . . . . . . . . . . 14

Variations of the Corn Plant . . . . . . . . . . . . 14

Corn and the Struggle for Democracy . . . . . . . . . . 15

Separate from Yearbook of the Department of Agriculture, 1918

No. 776 

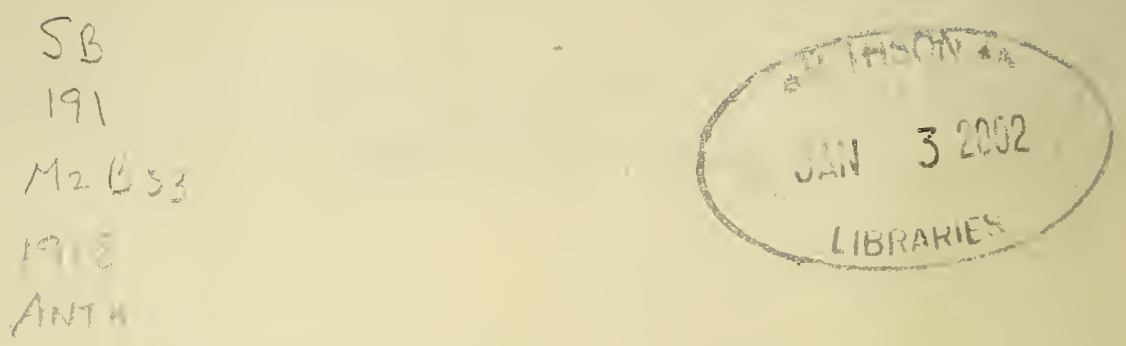

Smithsonian Institution

Libraries

Gift from

the Library of

JOHN C. EWERS 


\section{THE OLD AND THE NEW IN CORN CULTURE.}

By H. Howard Biggar,

Office of Corn Investigations, Bureau of Plant Industry.

\section{CORN THE GREAT AMERICAN CEREAL.}

CORN, the greatest of American cereals, is distinctively an $\cup$ American product. All evidence points to the fact that it was unknown in Europe until after the discovery of America. Its culture at an early period in this country is shown by the accounts of early explorers. Columbus, in writing to King Ferdinand and Queen Isabella in 1498, mentions cornfields in America 18 miles in length. Cartier, in the account of his explorations, states that the village of Hochelega, which later (in 1535) became Montreal, was situated in the midst of large cornfields. De Soto found large fields in Florida in 1675, and five years later La Salle noted large supplies in what is 'now the State of Illinois. That it was grown rather extensively is also indicated by the fact that in $16851,200,000$ acres of corn belonging to the Seneca Indians were destroyed by the English in New York. In 1696 Frontenac, who invaded the Onondaga country in New York State, spent three days in destroying growing fields.

\section{CORN AND THE EARLY COLONIES.}

The value of corn to the early colonists of the United States can hardly be overestimated. The Indians, through many years of experience, had learned the kinds of corn best suited to withstand varying conditions, and also some successful methods of corn culture. These facts were communicated to the colonists, who soon began growing corn. Corn was preferred to other cereal crops because it was easily cultivated, brought large returns in proportion to the amount of seed planted, and was an ideal feed for the production of hogs and cattle. Every man of John Smith's colony was given an acre of land and instructed to plant corn on it. Corn soon became a medium of exchange among the colonists. Taxes, rents, and debts were paid in corn, and $103843^{\circ}-19-1$ 
it was even bartered for marriage licenses. It is certain that on many occasions starvation would have overtaken the colonists had it not been for supplies of maize.

\section{CORN AND THE INDIAN.}

Upon the Indian, the first grower of corn, the cultivation of maize has exerted a more or less striking influence. Its cultivation in large fields made necessary a banding together of the individuals of the tribes. It was a sort of community or cooperative undertaking. With the cultivation of maize, the Indian brought northward the art of pottery making. Schoolcraft; the historian, states that mound building is associated with the growing of corn, being made necessary as a means of defense and easily accomplished because of the communal method of living.

The development of corn growing among the Indians encouraged the trading spirit. The corn of the Huron Indians in New York was exchanged for furs and other commodities. The agricultural Indian tribes of the Missouri Valley in North Dakota early dereloped a trade in corn and vegetables with the white traders and explorers, thus enabling the latter better to carry on their operations. They also traded with the hunting tribes of the Plains, securing furs, horses, and weapons, thus enabling them better to withstand invasion from powerful enemies. To the Plains hunters, the securing of corn meant prevention of famine in seasons when the hunting was poor. The trading equivalent of corn in the early days indicates its importance in the opinion of the Indian. Buffalo Bird Woman, a Gros Ventre of the Fort Berthold Reservation, states that a buffalo robe used to be given in exchange for a braid of corn containing about 50 ears. Red Bear, an Arikara of the same reservation, states that the Sioux Indians used to give his people a horse in exchange for 10 braids of corn.

The presentation of corn as a gift to other tribes and to the whites was common. It was the sign of friendship. Verendrye, in 1738, was met near the Mandan village, in what is now North Dakota, by a messenger who presented him with corn. Lewis and Clark, who wintered near this village, Maximillian and Verendrye, as well as other white 
traders and explorers, probably would have found it impossible to carry on their operations without the food (principally corn) obtained from the village Indians of the upper Missouri Valley.

Corn came to us as a gift from the Indians. Doubtless no other word in the Indian vocabulary is so important to the Indian, since for generations corn was the main food plant. The Indian's regard for corn is really a veneration. In the Middle West, the Corn Priest proclaimed the time to plant and to harvest the fields of corn and from time to time prayed that the crop might be a productive one. In the Southwest, corn shrines, corn dances, and numerous corn ceremonies are evidence of the regard of the Navajo, the Hopi, and the Zuni for their favorite cereal.

A study of the methods of corn culture of the various Indian tribes is of interest as showing the beginnings of what are now widely adopted practices. It also affords us an idea of primitive adaptation to conditions.

\section{KINDS OF CORN GROWN BY THE INDIANS.}

The Indians grew two main types of corn, Zea mays indurata, or the the flint corns, and Zea mays amylacea, or the flour corns. Inasmuch as corn was mainly used for human food, each type had its particular use. Flint corn was raised mainly for the making of hominy. Flour corn, because of its soft, starchy composition, was very easily ground in mortars. It was, therefore, especially valuable for parching and making into soups, puddings, and corn bread.

A distinguishing feature of the primitive Indian corns was their various colors. Among the kinds of corn grown were the following: Red-streaked flour, pink flour, white flour, red flour, blue flour, spotted flour, yellow flour, salmoncolored flour, white flour with kernels tipped with black, white flint, yellow flint, and pink flint. It must not be understood that all of these various kinds have passed out of cultivation. On the contrary, practically all of them can still be found, having been planted in small quantities from year to year, even up to the present time. An endearor was made to keep the various kinds separated by planting in fields apart from each other. 


\section{PRIMITIVE SEED-TESTING METHODS.}

Various methods of testing the germination of seed corn were practiced by the Indian tribes. On the Red Lake Reservation in northern Minnesota, corn was grown along the borders of Red Lake. The locality is more or less densely wooded; hence, use was made of moss in germinating seed previous to planting. A box was filled with moss, and kernels of corn were placed in the moss. The whole was soaked in water for a time and then set in a warm place until the kernels sprouted. Dead kernels were discarded, and the sprouted kernels were planted. Other tribes made willow baskets, filled them with kernels of corn, poured water through the corn, and placed the baskets in a warm place to start germination. Among the northern and western tribes, it seems to have been a general custom to soak the kernels of corn previous to planting, the object being to hasten the germination of the seed.

In connection with the soaking of the kernels, superstition played a conspicuous part. The older women of the tribes placed various substances in the water in which the corn was soaked. These substances were believed to influence the behavior of the future plant in the field and to insure its being free from plant diseases and other enemies. As an example of this might be cited the use of the ground plum (Astragalus caryocarpus). The fruits of this plant were often soaked in water with the corn. The ground plum is prolific, bearing many fruits, and it was the belief that its use in this connection would insure prolific corn crops.

THE NETTLE SEED TESTER.

It may be a surprise to many to know that a method of germination somewhat similar to our modern rag-doll seed germinator was used by middle-western tribes. The material used in this tester was the stem of the slender nettle (Urtica gracitis). It was used in the following manner :

When the time for planting corn was at hand, quantities of the nettle were gathered. They were piled in a sort of mat, and on this mat the kernels were placed. The mat of nettles was then rolled up so that it made a cylindrical 
bundle, with the corn kernels on the inside. The bundle was tied around with strings cut from buffalo hide and then immersed in water. After soaking for a day or two, the bundle of nettles was wrapped in a buffalo skin or other covering and kept warm. In a few days the kernels sprouted, and when the sprouts were a quarter of an inch or more long they were planted. Kernels not sprouting or showing swollen germs were not planted.

The slender nettle was used for this purpose because it was the first plant to reach any considerable height by cornplanting time. Furthermore, the fact that the plant was protected by stinging hairs, or spines, gave the Indians the idea that corn germinated with it would be protected from plant enemies during the growing season.

\section{PRIMITIVE CORN-PLANTING METHODS.}

Location and climatic differences are no doubt responsible for the fact that three distinct planting methods were in vogue among the Indians. These were as follows: (1) The Hopi method; (2) the Omaha, or mound, method; and (3) the usual "hill" metho'd.

The Hopi and other tribes of the Southwest, in order to reach moist soil in the sandy areas which they cultivate, make use of the planting stick in planting. This stick is about 3 feet in length and has a stiltlike projection about 10 or 12 inches from the bottom. The stick is pressed into the soil with the foot, and holes are made from 8 to 12 inches in depth. Into these holes as many as 20 kernels are dropped. The hills are about 10 feet apart. The number of plants in the hill may seem excessive, but none are thinned out, being left as a protection against wind and sun.

The Omaha, or mound, method was used by the Omaha Indians of Nebraska. In this method the earth was pulverized and heaped into mounds about 18 by 24 inches in area. The northern end of the mound was 18 inches in height, sloping to the south, the south end being level with the ground. The mounds were from 2 to 3 feet apart on all sides, and 7 kernels to the mound were planted. Sometimes a ditch was dug around the mound, into which water was poured in dry seasons. 


\section{INDIAN COKNFIELDS.}

The "hill" method of planting was the one usually followed by most of the tribes. Ground was selected as a rule along the banks of streams, trees were cut down and removed, weeds and rubbish were cleared away. Land where weeds grew was preferred because it was the easiest to prepare and was thought to be the most fertile. The fields were apt to be more or less irregular in shape, owing to the fact that they usually followed the bends of streams.

In preparing land for corn, the entire field was not dug up and pulverized, but only space enough for each hill. Each spring the stalks were removed from the hill, it was pulverized and again used for planting, so that the same hills used over and over became quite large and distinctive, marking in after years the location of former fields. Even the Indian understood the value of spacing hills and they were usually 2 to 5 feet apart.

Since the Indians practiced cooperation in their agricultural work to quite an extent, large fields of corn were really made up of hundreds of individual fields. Families helped each other at planting time and harvest in many instances, and at such times the fields presented a busy appearance. In the upper Missouri River valley in North Dakota as recently as 30 years ago, the Mandan, Arikara, and Gros Ventre tribes cultivated a tract of about 1,200 acres not far from the river banks. During the months of May and June this tract must have been an interesting place to visit. Here swarthy squaws toiled long hours in the hot sun, working with primitive tools, the small fields being separated from each other in much the same way that children's school gardens are to-day. At the outskirts of the fields Indian sentinels might have been seen guarding the workers from the attacks of hostile tribes. Later on, in the fall of the year, a procession of toilers wended their way from the fields with braids of corn, carrying them to the village for storage.

PRIMITIVE TOOLS.

A more or less gradual evolution in the kinds of tools used in corn culture has taken place. The most primitive tool was the sharpened hardwood stick. Later, the shoulder blades of the buffalo and deer, deer antlers, and clam and 


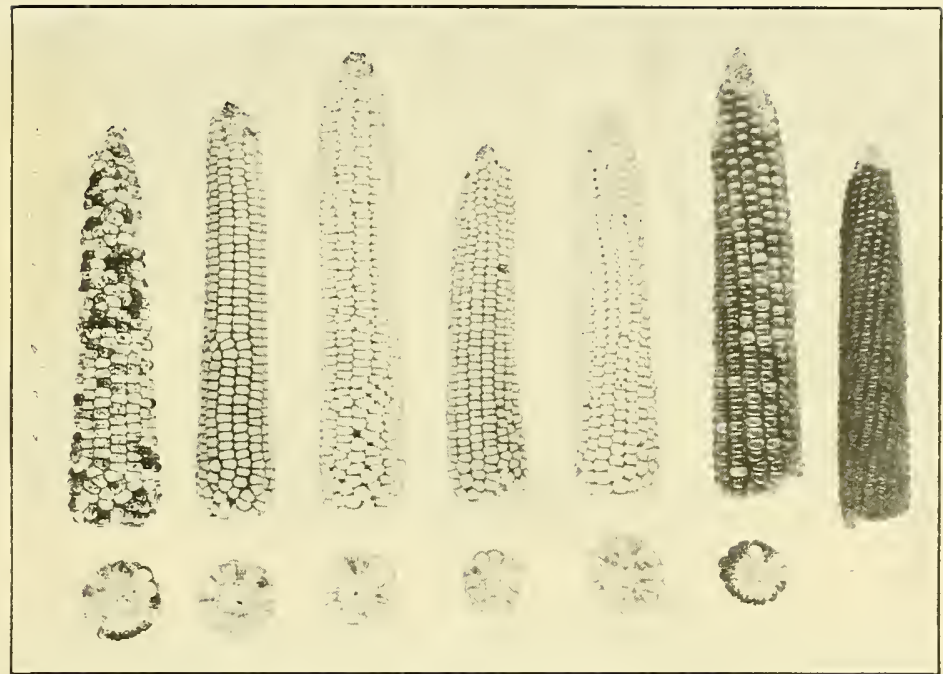

Fig. 1.-Types of CORN RaISEd by the Indians of the SOUTHWEST.

From left to right: Navajo birdsegg, Navajo yellow, Navajo white, Hopi yellow, Hopi white, Hopi blue, Hopi black.

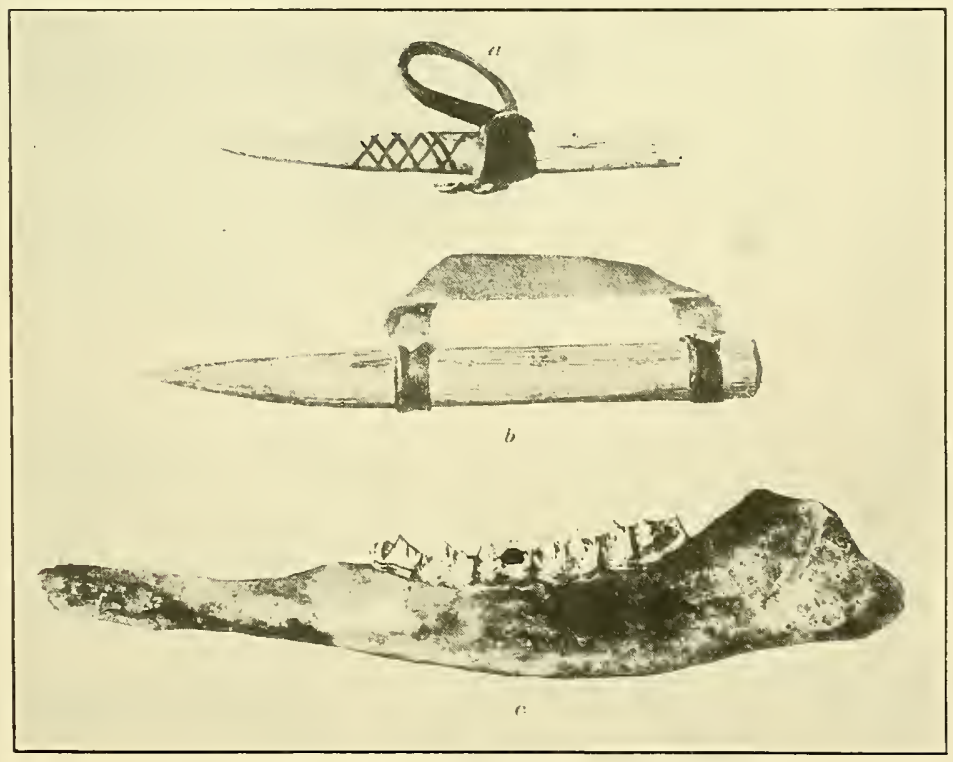

FIG. 2.-CORN HUSKING AND SCRAPING TOOLS.

(a) An Indian's corn-husking pin made of bear bone. (b) A white man's imitation of the above. (c) A scraper made from a deer's jaw and used by the Iroquois Indians for removing green corn from the cob. (Courtesy of the Canada Geological Survey.) 

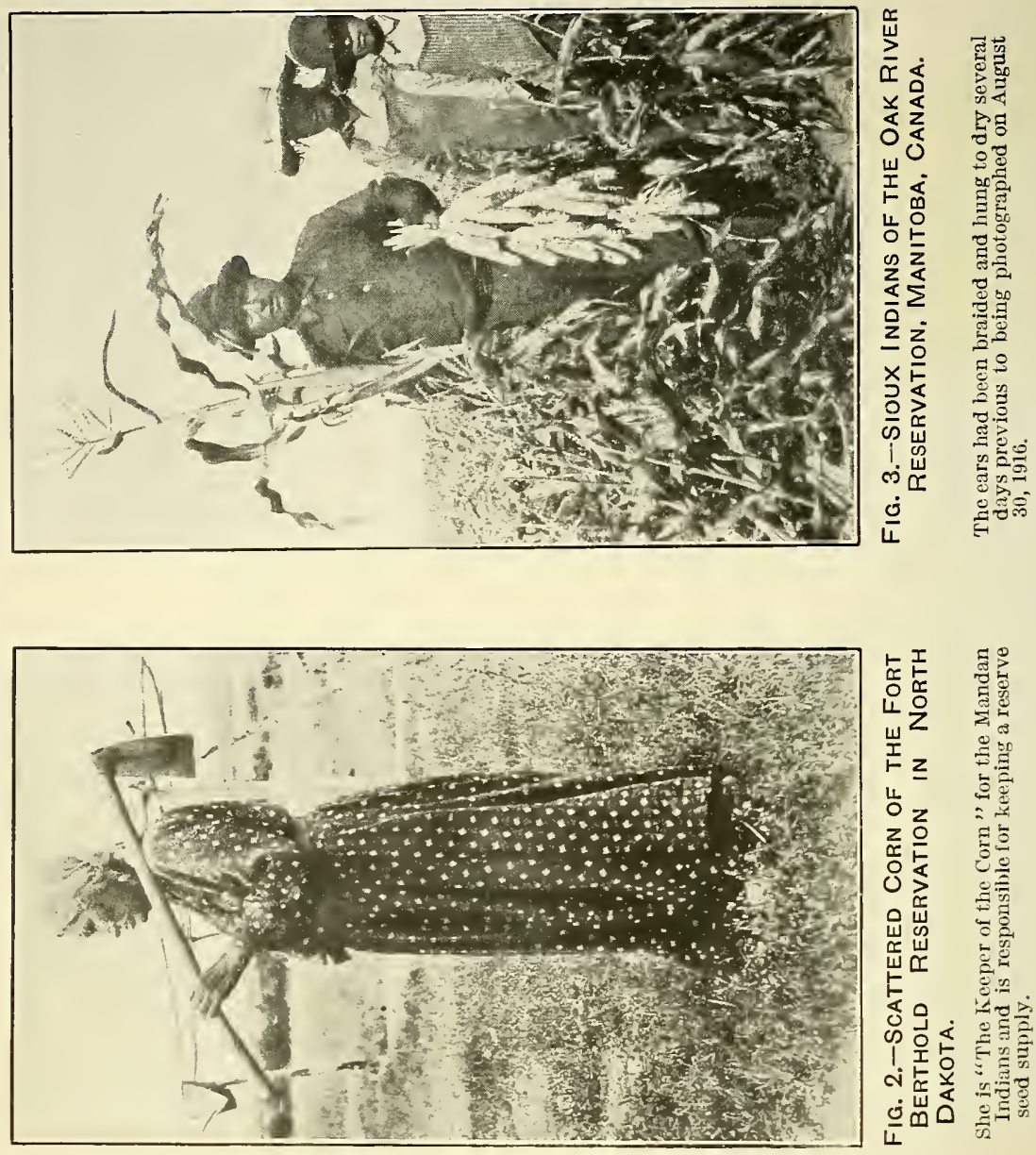

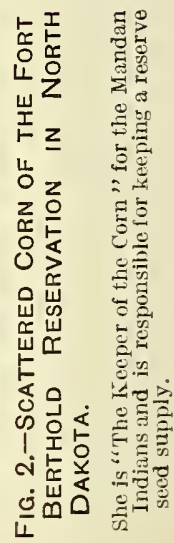

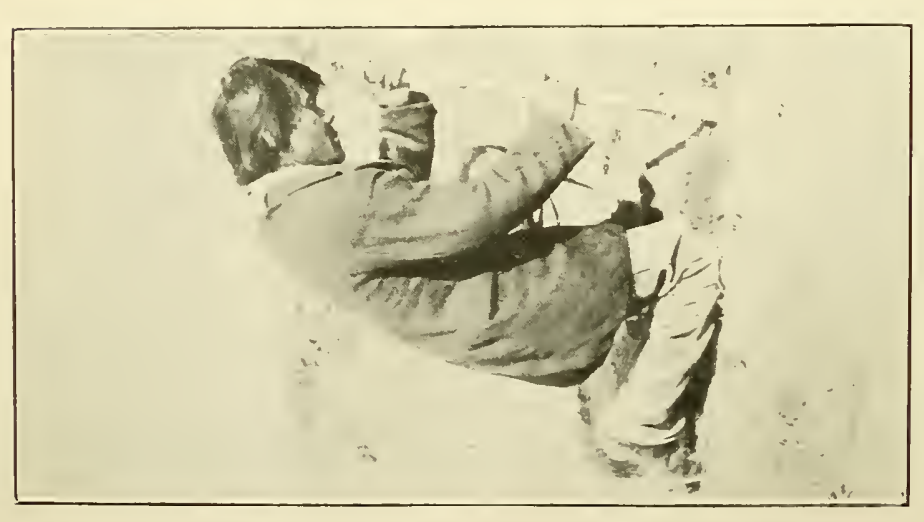

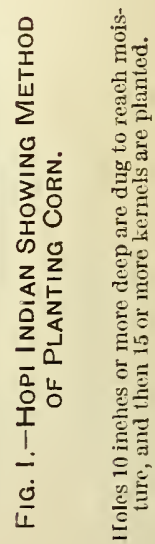




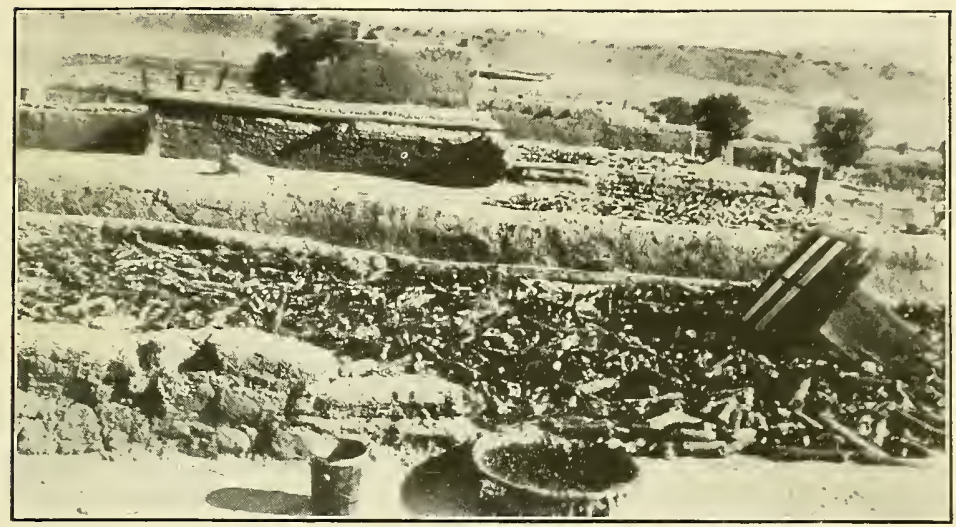

FIG. I.-PUEBLo METHOd OF DRYING CORN ON THE ROOFS, AT SAN FELIPE, N. MEX.

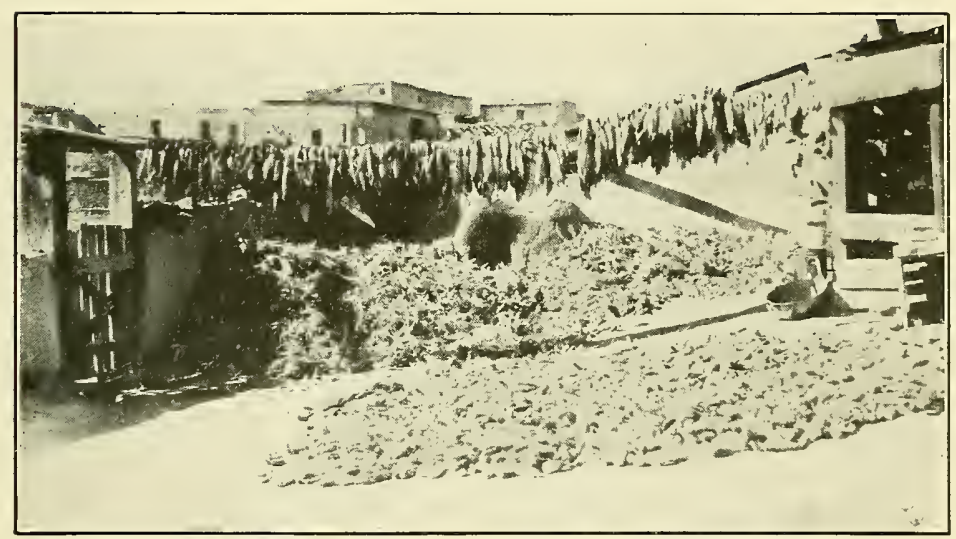

FIG. 2.-CoRn DRYing in a Yard at Laguna, N. Mex.

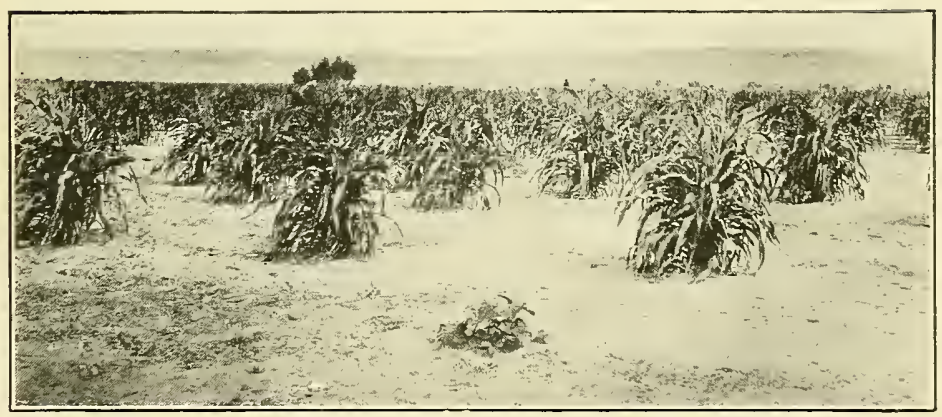

Fig. 3.-AN INDIAN CORNFIELd IN NEW MEXICO.

The hills are far apart, and the large number of plants in a hill afford protection from wind and sun. 


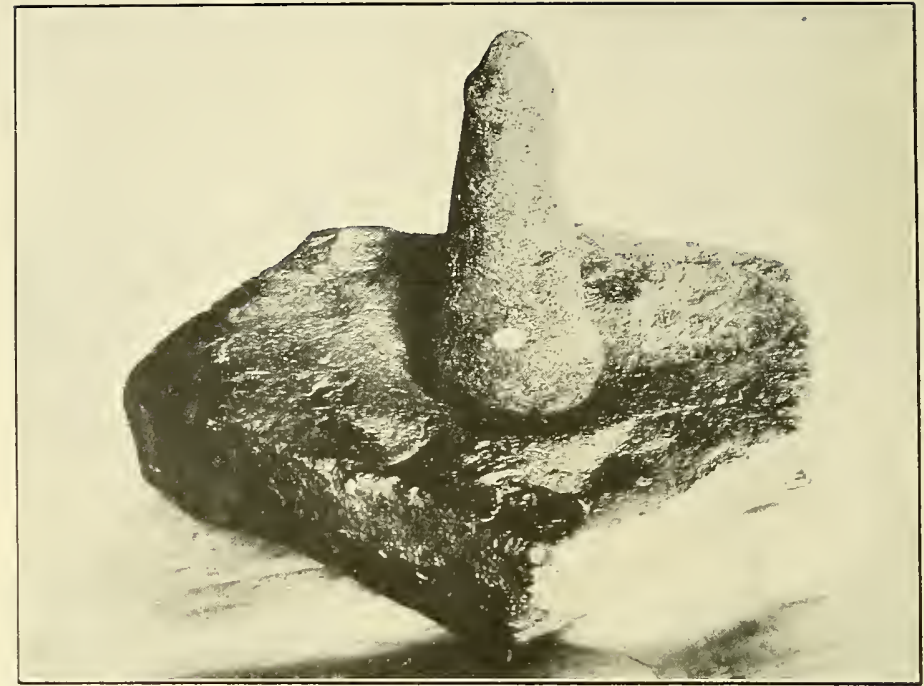

Fig. I.-STONe MoRTAR AND PEstle Used by the Indians of the MIDDLE WEST FOR GRINDING CORN.

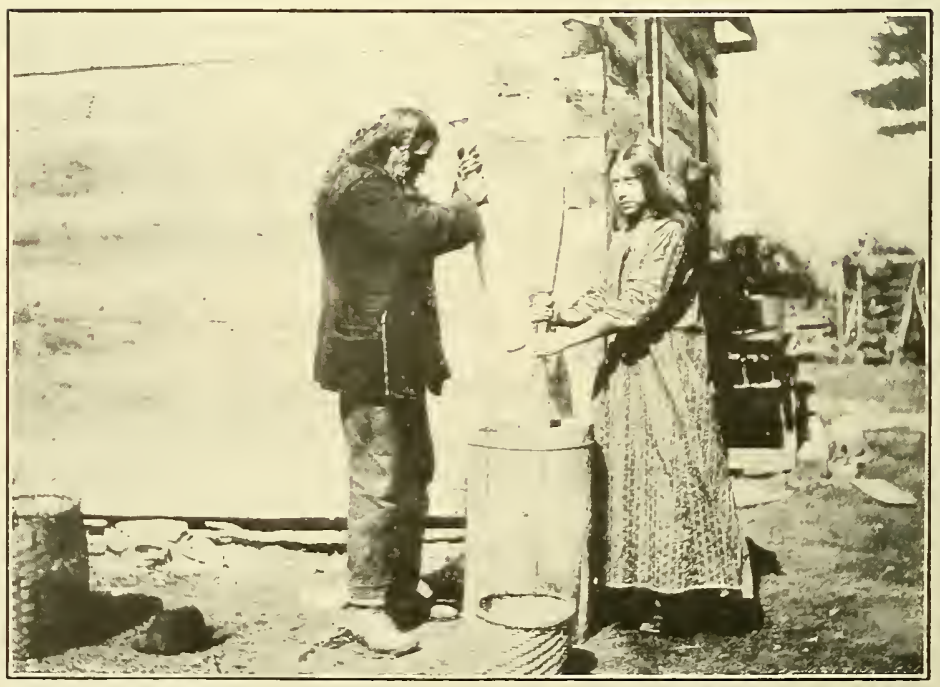

Fig. 2. - IROQUOIS INDIANS USING A WOOdEN MORTAR AND PESTLE to GRIND CORN.

Courtesy of the Canada Geological Survey. 
tortoise shells were used. In the Mississippi Valley, numerous stone and flint implements have been found which, from - their shape, suggest their use as primitive hoes or spades.

\section{PLANTS AS INDICATORS OF THE SEASON.}

There were three important periods in the field work of the agricultural Indians: (1) Planting time, (2) roasting-ear time, and (3) the harvest period. After planting, most of the members of the tribes left for other locations for the summer hunt. Usually, some of the women were left to attend to the weeding out of the patches. At roasting-ear time, many returned from the hunt to gather corn and prepare it for food, much of it being parched and put away for future use. When the ears were ripe, both men and women joined in the harvest.

It is of interest to note that the time to return from the hunt to gather the roasting ears and the ripe ears was indicated to the hunters by the appearance of prairie flowers, the Indians having learned the relations between the growth stages of corn and other plants. One of these indicator plants was the blazing star, or buttonweed, whose habitat includes the States of the Middle West. According to an informant of the Omaha tribe in Nebraska, this plant was used as follows: When the Indians on their hunting trips saw the first small flower buds appearing on the blazing star, they knew that the corn in their fields at home was approaching the milk stage. When the buds were entirely open, the corn was ready for parching and it was time to return. Later in the season, when the plant was through blossoming, they knew that the corn was ripe and it was time to harvest. Other plants used as indicator plants on the Plains were the cat-tail and the goldenrod.

\section{SEED SELECTION AND STORING.}

The Indians practiced seed selection and had definite standards. Many tribes discarded the butts and tips, planting only the middle portions of the ears. Some tribes discarded ears with moldy cobs or with irregular rows. Wellfilled ears were preferred, with straight rows of kernels. 
Seed ears were selected each fall and the husks braided together, so that a braid would contain about 50 ears and would be about 5 feet long. Practically all the Indian tribes, seem to have practiced braiding. The tribes of the Southwest hung the braids up to dry or else spread unbraided ears on the ground or on the roofs of their flat-topped houses. After the drying was completed, the corn was stored in the lower stories of the dwellings. Some of the southwestern tribes used large storage baskets.

The Indians of the New England and Middle-Western States used the cache for storing corn and other foodstuffs. These caches were holes dug in the ground, usually to a depth of 5 to 7 feet and several feet in diameter. They were either jug shaped or cylindrical. Although the fields of corn were usually on the lower lands, the caches were dug on the higher ground so as to avoid danger from seepage waters. Caches were dug either inside or outside of the dwellings. Considering the rude tools at the disposal of the Indians, the digging of a cache was no small task.

Shelled corn and braided corn were both put in the caches. Usually the shelled corn was placed in buffalo or deer-skin sacks before caching. Indians in the forest country cached their corn after placing it in bags made of cedar bark. A fire was often started in the cache after completion, in order to dry it out before storing corn. Grass and bark were used in lining the sides and bottoms. The final covering was earth, and when well covered the cache could not be distinguished by strangers, and so was not in much danger of being robbed. Sometimes one family had as many as two or three caches.

\section{INDIAN CORN FOODS.}

The colonists obtained their first knowledge of how to use corn as a food from the New England Indian tribes. Capt. John Smith, in his accounts, mentions the preparation of sereral corn foods. The Iroquois Indians had at least 40 different ways of cooking corn. The "travelling food" of this tribe is an interesting example, as showing Indian food combinations. Soft or flour corn was used. It was shelled and parched slightly in the embers of a wood fire. Then it was thrown into a mortar, maple sugar was added, and it was 
pounded and sifted until it was a very fine meal. Sometimes dried fruits, such as cherries, were pulverized with it. The food was carried on hunting expeditions and in time of war. One-fourth of a pound, diluted in a pint of water, was a good dinner.

Succotash was a dish prepared by New England and middle-western tribes. Corn was cut from the cob, placed in a kettle with a quantity of beans, and then boiled. Salt and butter were added as seasoning.

According to Dr. Walter Hough, of the National Museum, the Hopis had 52 kinds of corn foods. One of the main ones was prepared as follows: Large pits were dug in the sand. They were heated with burning brush, filled with roasting ears, and tightly closed for a day. When the pit was opened, corn feasts were held.

Hominy was a food used by most of the northern and middle-western tribes. Wood ashes were used to make lye water for removing the hulls. Flint corn kernels were placed in the water with the wood ashes. The water was boiled until the hulls were removed, then rinsed off, put into another kettle with clear water, and boiled.

A food of the Gros Ventre Indians, called "husared," was prepared by grinding corn and placing it in corn husks. The husks were folded over with the corn on the inside, tied up, and then dipped into boiling water.

Corn smut (Ustilago zea) was often used as a food by some tribes. The Gros Ventre tribe gathered the smut, boiled it, dried it, broke it into bits, and ate it with corn as a relish. It is said to have tasted like corn and was very palatable.

\section{PRIMITIVE AND MODERN METHODS OF CULTURE.}

The evolution in methods of corn culture since the primitive days when the Indians cared for their main food plant may seem very striking. In comparing, however, the practices of the red man with our modern methods of corn culture, we must not fail to recognize his ingenuity and foresight. Modern tools were not available. Years of experimental evidence as to the wisdom of this or that step were wholly lacking. In view of these facts, the Indian's utilization of materials at hand and his methods of procedure 
are to be commended. The Indian had no means of recording time. He watched the forces of nature in planning his agricultural work. Seed was prepared and corn was planted when the wild turnips began to bloom, when grass became green, when plums, wild grapes, or juneberries began to blossom, or when the leaves of the trees began to uncurl.

In lieu of our modern tillage machines, the squaws of the tribes worked up the ground with tools wrought from wood, bone, or stone. The number of kernels planted per hill has not materially changed even to this day. The principle of spacing hills and the distance apart of hills are about the same to-day as in primitive times. Special attention was given to the type of seed ear, the drying of seed, and the testing of germination in primitive testers; all these indicate an almost uncanny knowledge on the part of the Indian agriculturist, quite in keeping with our emphasis on these points to-day.

It is a far cry from the cache to the modern well-ventilated corn crib, but the utility of the cache as a burglarproof storage house can not be denied. Domestic-science experts, skilled in methods of utilization of corn as a food, must not fail to recognize primitive housekeeping skill as exemplified in the scores of corn foods prepared and used by the Indians.

\section{CORN AND THE WESTWARD MOVEMENT.}

The story of Indian corn is the story of the struggle of the human race for food in the Western Hemisphere. It is the story of definite rotations where corn is the cultivated crop. The dependence of the Indian upon corn, how it called into play his inventive genius, and its adoption as a crop and a food by the early colonists have been mentioned. Its popularity among the colonists resulted at last in a corn surplus, which was sent to the West Indies and South America in exchange for products of those countries.

A steady influx of population along the Atlantic coast made more agricultural land necessary. The westward movement began, and settlements were made beyond the Alleghenies, where much of the soil was found to be especially suitable for corn production. The feeding of live stock began, and the surplus corn crop from west of the Alleghenies 
moved to the East in the shape of cattle and hogs. It was a not uncommon sight to see large droves of cattle and hogs being driven across the mountains from the Ohio Valley to Baltimore. Increasing trade with the eastern part of the United States and the beginnings of European trade made systems of transportation necessary. National highways were opened, canals were constructed, and at last railroads linked widely separated territory, so that the products of the West could reach quickly the eastern cities, the Atlantic seaboard, and the Orient.

The progress of invention and commerce was hastened by rapidly increasing supplies of corn and corn-fed animals.

\section{CORN AND THE PACKING INDUSTRY.}

The increasing production of corn and the consequent increase in hogs and cattle developed the packing-house industry. About 1832 the city of Cincinnati was nicknamed "Porkopolis" because of its importance as a pork-packing center. The Union Stock Yard and Transit Co. of Chicago began its operations in 1865. For a number of years it remained the only large market. In 1871, 1874, 1877, 1881, and 1898, stockyards were established at Kansas City, St. Louis, Sioux City, South Omaha, and St. Joseph. The growth of the packing industry has been indeed rapid. According to the Interstate Commerce Commission reports, there is a steady growth in the tonnage of packing-house products carried by the railways in the United States. For the years 1914, 1915, and 1916, the report of tonnage is as follows:

Tons.
1914 -
1915 -
1916 - 139,000

The increasing utilization of by-products of the packing houses is more or less familiar to all of us. As for the movement of live stock from the farms to various markets, live stock whose ration to a greater or less extent is corn, figures are so large as to be almost incomprehensible. According to the Bureau of Markets of the Department of Agriculture, the receipts of hogs during the 5 years from 1913 to 1917 at 12 leading markets averaged over $26,000,000$ animals annually. The increase in receipts for this period over the 
previous 5 years is 14 per cent. In the year 1917 these same 12 markets received more than $14,000,000$ cattle.

THE SILO AND THE CORN CROP.

No single agricultural step in marking the advance of methods of utilizing corn has been so important as the preservation of the crop in the green state in the silo. Between 1860 and 1870 the first silos for corn were used in Europe. The first record of silo construction in this country was in 1875, when two were built and used in Michigan. The days of experimentation with silage have now passed. Because it is an economical means of utilizing green feeds, especially corn, silage construction and the use of the silo are increasing rapidly, particularly in the dairy States. The following table shows the States leading in the number of silos:

Number of silos in the United States.

[From the Monthly Crop Report, August, 1917, of the Bureau of Crop Estimates.]

\begin{tabular}{|c|c|c|c|}
\hline \multirow{2}{*}{ State. } & \multirow{2}{*}{$\begin{array}{l}\text { Number } \\
\text { of silos. }\end{array}$} & \multicolumn{2}{|c|}{ Capacity (tons). } \\
\hline & & A verage: & Total. \\
\hline 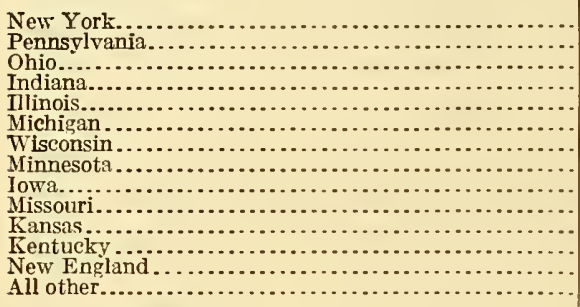 & $\begin{array}{l}55,000 \\
24,000 \\
25,000 \\
27,000 \\
30,000 \\
33,000 \\
55,000 \\
15,000 \\
16,000 \\
13,000 \\
11,000 \\
10,000 \\
35,000 \\
55,000\end{array}$ & $\begin{array}{r}75 \\
65 \\
67 \\
70 \\
79 \\
70 \\
87 \\
95 \\
105 \\
90 \\
106 \\
80 \\
67 \\
77\end{array}$ & $\begin{array}{l}4,125,000 \\
1,560,000 \\
1,675,000 \\
1,890,000 \\
2,370,000 \\
2,310,000 \\
4,785,000 \\
1,425,000 \\
1,680,000 \\
1,170,000 \\
1,166,000 \\
800,000 \\
2,345,000 \\
4,235,000\end{array}$ \\
\hline United States...... & 404,000 & 78 & $31,536,000$ \\
\hline
\end{tabular}

The arerage number of milch cows in the United States in the decade 1908 to 1917 was 20 per cent more than in the previous decade. A large part of this increase is no doubt due to the growing popularity of the silo as a cheap means of preserving green feeds.

\section{VARIATIONS OF THE CORN PLANT.}

Whatever may have been the origin of corn, the fact remains that in its distribution over the United States it has undergone many and diverse modifications. Sturtevant re- 
ports heights of stalks varying from 18 inches for Golden Thumb pop corn to 22.25 feet for corn in Tennessee, and also reports individual ears with rows of kemels varying from 4 to 48 . Variations in color are almost unlimited. Montgomery states that there are now probably 1,000 named varieties of corn in the United States, three-fourths of which have been developed since 1840. In 1898 Sturtevant listed 507 varieties.

Corn has shown especial adaptability to differences in length of seasons, and at the present time we find varieties maturing in 80 days in the North and other varieties requiring 150 days or more in the South. The types, consisting of pop, flint, flour, dent, sweet, and pod corns, indicate great changes in centuries of adaptation. In addition to their natural variations, but few plants in America have received more attention at the hands of the plant breeder than corn.

The plant breeder has found the plant to be very mobile, responding readily to selection. Proof of this is shown by the fact that selection has been found to influence the following characters: Shape of ear, height of ear, percentage of protein, percentage of oil, type of kernel, type of ear, width of leaves, color of kernel, size of cob, and many other characteristics. Through hybridization, valuable characters of different varieties have been brought together.

\section{CORN AND THE STRUGGLE FOR DEMOCRACY.}

Corn played a vital part in the European conflict. In response to widespread appeals, the acreage in 1917 was increased more than 10 per cent compared with 1916 and approximated $117,000,000$ acres. The crop of $3,065,000,000$ bushels was next to the largest ever harvested. If this crop had been loaded on wagons, each containing 50 bushels and allowing 20 feet of space for each wagon, these wagons placed end to end would make a line long enough to encircle the globe $9 \frac{1}{2}$ times.

The importance of corn in the agriculture of the United States is well shown by the fact that in the decade 1908 to 1917 the acreage devoted to corn in this country was 4.8 per cent greater than the combined acreage of the crops of wheat, oats, barley, rye, rice, buckwheat, and flax. The value of the corn crop for the same period was 24.3 per 
cent more than the combined values of these crops. During the same decade, the number of acres in corn was 18.7 per cent in excess of that for the previous decade. A growing increase in the price per bushel for corn is indicated by the fact that the value of the crop was about 100 per cent greater in the past decade than in the previous one.

In many forms, corn is becoming more and more popular as a human food. It is the main cereal food of the cotton belt. Considering the food value of crops grown on an acre of land, corn heads the list, a 35-bushel crop producing. nearly 150 pounds of protein and more than 3,000,000 units of energy.

Valuable, even in the remote past, as a sustainer of life: among primitive peoples in peace and war, the importance of corn in the world's affairs becomes more and more manifest with each decade of time. Moving westward and northward as its merits became better recognized, its growth in production is closely associated with the building of canals, railroads, our national highways, and our commercial supremacy. Because of the manifold uses of every part of the plant, the production of corn is closely linked with the development and perpetuation of many great industries. Because of its wonderful adaptation to conditions, it is now grown with success in every State of the Nation, from sea level to lofty plateaus. In acreage, in multiplicity of uses, in production, and in value it exceeds any other cultivated crop. A corn-crop failure of any extent affects our supply of meat, lard, butter, and imports and exports. Its use as a substitute for wheat made it possible to release exceptionally large shipments of wheat to Europe, to supply the Allies and our own armies.

Having served a useful purpose in the early days of our country's history, corn is still indispensable in the development and perpetuation of our great Republic.

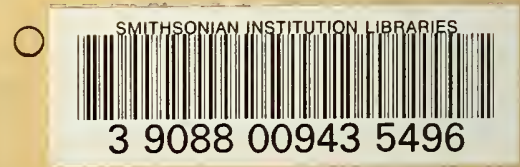

